\title{
JALUR DISTRIBUSI PEMASARAN SAPI POTONG DI MASA PANDEMI COVID-19
}

\author{
Beef Cattle Marketing Pathway during the Covid-19 Pandemic \\ Lius Djailani ${ }^{1.4}$, Muhammad Mukhtar ${ }^{2}$, Sri Yenny Pateda ${ }^{2}$, dan Supriyo Imran ${ }^{3}$ \\ ${ }^{1}$ Program Pasca Sarjana Universitas Negeri Gorontalo \\ ${ }^{2}$ Prodi Peternakan Fakultas Pertanian Universitas Negeri Gorontalo \\ ${ }^{3}$ Prodi Agribisnis Fakultas Pertanian Universitas Negeri Gorontalo \\ ${ }^{4}$ Fasilitator Dinas Sosial Kabupaten Gorontalo \\ Jl. Trans Sulawesi, Mootilango, Kabupaten. Gorontalo, 96119 \\ *Coreponding Author: email: liusdjailani@gmail.com
}

\begin{abstract}
The purpose of the study was to determine marketing distribution channels, profits, and the value of beef cattle marketing efficiency in each marketing agency during the covid-19 pandemic. This research was carried out in September-November 2020 in Gorontalo Regency. This research is using survey method, and analyzed descriptively. The results showed that the marketing distribution channel for beef cattle in Gorontalo Regency during the pandemic there were 2 (Two) direct marketing distribution channels and 3 (Three) indirect distribution channels. Distribution margin I during the pandemic is Rp.0, distribution channel II is Rp. 3,000,000, distribution channel III Rp. 6,000,000, distribution channel IV Rp. 4,000,000, distribution channel V Rp. 4,000,000. The marketing efficiency of beef cattle lies in the distribution channel I of $0.5 \%$, and $\mathrm{V}$ of $0.05 \%$, while the other lines are inefficient. During the Covid 19 pandemic, an efficient beef cattle marketing channel is a direct marketing channel
\end{abstract}

Keywords: Covid-19, Marketing Efficiency, and Beef Cattle Marketing

\begin{abstract}
ABSTRAK
Tujuan penelitian untuk mengetahui jalur distribusi pemasaran, Margin keuntungan tiap lembaga pemasaran dan nilai efisensi pemasaran sapi potong dimasa pandemi covid-19. Penelitain ini telah di lakukan pada bulan September-November 2020 di Kabupaten Gorontalo. Penelitian ini menggunakan analisis deskriptif. Hasil penelitian menunjukan bahwa jalur distribusi pemasaran sapi potong dikabupaten Gorontalo disaat pandemi terdapat 2 (Dua) jalur distribusi pemasaran langsung dan 3 (Tiga) jalur distribusi tidak langsung. Margin distribusi I pada masa pandemi adalah Rp.0, jalur distribusi II Rp. 3.000.000, jalur distribusi III Rp. 6.000.000, jalur distribusi IV Rp. 4.000.000, jalur distribusi V Rp. 4.000.000. Efisiensi pemasaran sapi potong terletak pada jalur distribusi I sebesar $0,5 \%$, dan $\mathrm{V}$ sebesar $0,05 \%$, sedangkang jalur lainnya tidak efisien. Jalur pemasaran lansung memiliki nilai efisen yang baik. Dimasa pandemi Covid 19, Jalur pemasaran sapi potong yang efisien adalah jalur pemasaran langsung
\end{abstract}

Kata Kunci : Covid-19, Efisensi pemasaran, dan Pemasaran Sapi Potong

APA Citation Style

Djailani L., M Muhammad, Pateda Y S., dan Imran S. 2021. Jalur Distribusi Pemasaran Sapi Potong di Masa Pandemi Covid-19. Jambura Journal od Animal Science 4(1)34-40

@ 2021 - Djailani L., M Muhammad, Pateda Y S., dan Imran S. The under License. CC-BY-NC-SA 4.0 


\section{PENDAHULUAN}

Peternakan adalah sektor yang memiliki peluang sangat besar untuk dikembangkan sebagai usaha di masa depan, dilihat dari kebutuhan masyarakat terhadap produk peternakan semakin meningkat setiap tahunnya, sedangkan ternak potong local belum mampu memenuhi kebutuhan dalam negeri., sehingga inport daging masih merupakan salah satu cara untuk mengatasi kekurangan daging. Pemasaran pada prinsipnya merupakan proses kegiatan penyaluran produk yang dihasilkan oleh produsen agar dapat sampai kepada konsumen, bagi produsen sapi potong, baik perusahaan peternakan maupun peternakan rakyat pemasaran mempunyai peran yang penting. Setelah produk dihasilkan, peternak pasti menginginkan ternaknya cepat sampai dan diterima oleh konsumen. Berdasarkan fenomena dan kenyataan di atas, masyarakat peternakan di Kabupaten Gorontalo memanfaatkan kesempatan tersebut sebagai peluang usaha peternakan khususnya sapi potong. Potensi ekonomi subsektor peternakan dapat di manfaatkan secara berkelanjutan dan mampu memberikan kontribusi dalam meningkatkan kemakmuran rakyat, sedangkan di sisi lain ada tantangan besar yang harus dihadapi seperti keterbatasan modal, rendahnya wawasan agribisnis, tatalaksana pemeliharaan tradisional yang mendominasi pemeliharaan ternak dan Kenaikan harga daging sapi dimasa pandemic Covid-19 terus meningkat. Menurut Noor (2020), harga komoditas pangan pokok sebelum dan saat pandemi Covid-19 menunjujan adanya penigkatan yang fluktuatif.

Masa pandemi Covid-19 terjadi banyak sekali perubahan harga terkait dengan pemasaran ternak yang ada di Kabupaten Gorontalo, harga yang dijual oleh peternak ke pedagang mengalami penurunan dari harga sebelum masa pandemi Covid-19. Menurut (Lasaharu \& Boekoesoe, 2020) jalur pemasaran ternak sapi potong memiliki nilai efisiensi 0.26-3.1 disetiap lembaga pemasaran. Kondisi pemasaran seperti ini pelu dikaji, apa yang menyebabkan turunnya harga ternak di pasar sementara bantuan untuk Covid terus diberikan oleh pemerintah. Kemungkinan aspek pemasaran ditingkat peternak sangat terbatas karena peternak tidak bisa langsung menjual hasil ternak mereka kepasar, karena adanya peraturan Pemerintah seperti loock down, pembatasan kerumunan dan lainnya. Peternak mengalami kendala untuk mengetahui kondisi dan perkembangan pasar ternak. Anugrah, I. S., dkk (2020) Dampak pandemic Covid-19 di tingkat produsen, tidak mempengaruhi proses dan jumlah produksi, terjadi keterbatasan penyerapan produk saat PSBB dibandingkan sebelum pandemi Covid-19, harga produk produsen menurun dan pada akhirnya para petani mengalami kerugian usaha tani. Tujuan Penelitian untuk mengetahui pola jalur distribusi pemasaran ternak sapi pada masa pandemi covid-19

\section{METODE PENELITIAN}

Penelitian ini telah dilaksanakan sejak bulan September-November Tahun 2020. Lokasi penelitian adalah di Kabupaten Gorontalo. Pemilihan lokasi berdasarkan populasi ternak sapi yang ada tingkat peternak diwilayah Kabupaten Gorontalo. Penentuan populasi dan sampel disetiap lembaga pemasaran dengan teknik cara random sampling. jumlah sampel sebanyak yaitu 53 peternak, 5 pedagang pengumpul, 5 pedagang besar, 5 pedagang pasar dan 20 konsumen yang ada di Kabupaten Gorontalo

Analisis deskriptif digunakan untuk menggambarkan tentang jalur distribusi pemasaran sapi potong, margin tiap lembaga pemasaran, dan efisiensi dari lembaga pemasaran sapi potong. Analisis deskripsi mengikuti saran (Lasaharu \& Boekoesoe, 2020); (Abdi, Usman Rianse, 2012) 
Margin Tiap Lembaga Pemasaran ternak sapi potong ( Lasaharu, 2020, )

Dimana $=$

$$
\mathrm{M}=\mathrm{Hp}-\mathrm{Hb}
$$

$$
\begin{aligned}
& M=H p-H b \\
& M=\text { Margin Lembaga Pemasaran } \\
& H p=\text { Harga Penjualan (Rp/Ekor) } \\
& \mathrm{Hb}=\text { Harga Pembelian (Rp/ Ekor) }
\end{aligned}
$$

Untuk Mengetahui Besarnya keuntungan dari masing-masing lembaga pemasaran, digunakan rumus :

$$
\begin{aligned}
& \qquad \Pi=\mathrm{ML}-\mathrm{TC} \\
& \text { Dimana : } \\
& \Pi=\text { Keuntungan Lembaga Pemasaran (Rp/ekor) } \\
& \mathrm{ML}=\text { Margin Lembaga Pemasaran (Rp/ekor) } \\
& \mathrm{TC}=\text { Biaya total pemasaran yang dikeluarkan tiap lembaga Pemasaran (Rp/ekor) }
\end{aligned}
$$

Untuk mengetahui efisiensi jalur distribusi pemasaran di gunakan rumus :

Dimana :

$$
E p=\frac{B P}{N P} \times 100 \%
$$

$$
\begin{aligned}
& \text { Ep }=\text { Efisiensi Pemasaran }(\%) \\
& \text { BP }=\text { Total Biaya Pemasaran (Rp/ekor) } \\
& \text { NP }=\text { Total Nilai Produk yang dipasarkan (Rp/ekor) }
\end{aligned}
$$

HASIL DAN PEMBAHASAN Jalur distribusi Pemasaran Sapi Potong Hasil penelitian menunjukkan bahwa terdapat beberapa tingkatan lembaga pemasaran yang berperan dalam pemasaran sapi potong di kabupaten Gorontalo sebelum masa pandemic Covid-19.

Tabel 1 : Jalur distribusi Pemasaran Sapi Potong Pada Masa Pandemi Covid-19

\begin{tabular}{lcc}
\hline \multicolumn{1}{c}{ Uraian } & Masa Pandemi Covid-19 & Keterangan \\
\hline Jalur distribusi Pemasaran I & P-K & Sama \\
Jalur distribusi Pemasaran II & P-PP-PB-K & Tidak Sama \\
Jalur distribusi Pemasaran III & P-PP-PPG-PS-K & Sama \\
Jalur distribusi Pemasaran IV & P-PPG-K & Tidak Sama \\
Jalur distribusi Pemasaran V & P-PS-K & Tidak Sama \\
\hline
\end{tabular}

Keterangan:

$$
\begin{array}{ll}
\mathrm{P} & =\text { Peternak } \\
\mathrm{PP} & =\text { Pedagang Pengumpul } \\
\mathrm{PB} & =\text { Pedagang Besar } \\
\text { PPG } & =\text { Pedagang Pemotong } \\
\text { PAT } & =\text { Pedagang Antar Pulau } \\
\text { PS } & =\text { Pedagang Pasar } \\
\mathrm{K} & =\text { Konsumen }
\end{array}
$$

Berdasarkan tabel 1, Terdapat 5 jalur pemasaran pemasaran sapi potong, jalur distribusi pemasaran I dan jalur distribusi pemasaran III jalur distribusi pemasarannya sama, tidak ada prubahan masa pandemi covid-19 yakni dari peternak langsung konsumen. Jalur distribusi pemasaran III di masa pandemic covid-19, yakni dari Peternak - Pedagang Pengumpul - Pedagang Pemotong Pedagang Pasar - Konsumen. Pola jalur distribusi pemasaran II, IV, dan V dimasa pandemic Covid 19 merupakan distribusi pemasaran yang baru, Hal ini terjadi karena adanya lembaga pemasaran baru yang berbeda dan ikut berperan dalam kegiatan distribusi yaitu Pedagang Pemotong (PPG), selain itu ada perubahan jalur distribusi misalnya pedagang besar sudah melayani permintaan konsumen local, dan tidak melakukan perdagangan antar pulau atau antar Provinsi. Hal ini 
dikarenakan ada pemberlakuan Pembatasan Sosial Berkala Besar (PSBB) di masa pandemi covid-19 dan kurangnya pesanan dari luar daerah. Hal ini sejalan dengan pernyataan Sudarmono dan Sugeng (2008) Jalur distribusi distribusi ada dua yaitu jalur distribusi distribusi langsung dan jalur distribusi tidak langsung. Jalur distribusi tidak langsung biasanya pengusaha menggunakan pihak luar untuk membantu menyalurkan barang-barangnya kepada konsumen. Jalur distribusi distribusi langsung biasanya pengusaha berusaha untuk menyalurkan barang-barang yang dibeli konsumen secara langsung dengan tujuan konsumen merasa puas karena tidak perlu memikirkan masalah pengangkutan barang yang dibelinya. Jalur pemasaran sapi potong sebelum masa dan masa pandemic covid 19 ditunjukan dalam gambar 1

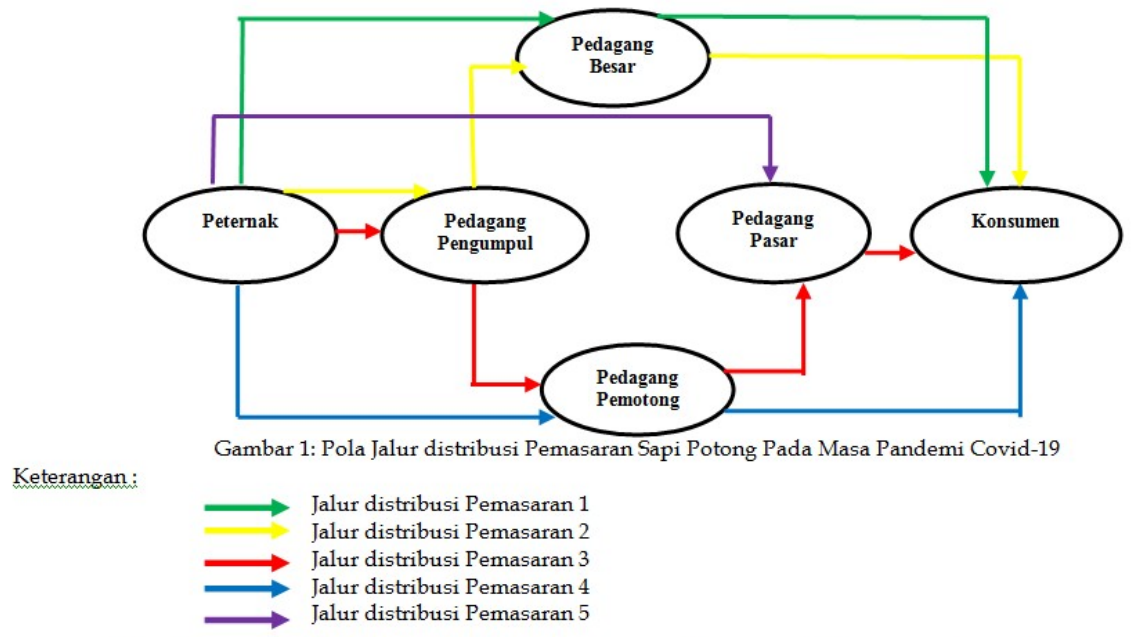

Berdasakan Gambar 1 selama pandemic COVI-19 terdapat 5 jalur pemasaran, penjualan sampai ke luar Gorontalo yakni ke Kalimantan tidak lagi dilakukan, dikarenakan jalur pemasaran yang dibatasi karena adanya pandemi, sehingga pengeluaran ternak sapi keluar Gorontalo dengan sendirinya terhenti atau tidak ada permintaan. Keputusan ini dilakukan oleh lembaga pemasaran terbesar disebabakan kondisi pandemic 19, banyak aturan yang harus di ikuti dan membutuhkan waktu yanglam atau bias dianggap tidak praktis. Keputusan lembaga peternak dalam melakukan pembelian input produksi bergantung dengan kondisi pasar dan kebijakan pemerintah yang membatasi pergerakan selama masa pandemic 19 , (Hakim, 2021). Jalur distribusi ada dua yaitu jalur distribusi distribusi langsung dan jalur distribusi tidak langsung. Jalur distribusi distribusi tidak langsung biasanya

pengusaha menggunakan pihak luar untuk membantu menyalurkan barangbarangnya kepada konsumen (sudarmono dan sugeng, 2008). Saluran pemasaran I yang dilalui merupakan saluran terpendek yakni hanya terdapat satu saluran pemasaran. Peternak menjual langsung ke pedagang di pasar, sedangkan saluran lainnya peternak tidak menjual langsung ke pedagang yang adai pasar ternak (Agustin, M., \& Hayati, M. 2020).

Marjin dan Keuntungan Jalur distribusi Pemasaran

Setiap lembaga pemasaran berusaha untuk mendapatkan keuntungan dari kegiatan usahanya dalam pemasaran ternak sapi potong. Kegiatan usaha yang dilakukan adalah untuk meningkatkan tambahan nilai guna dari ternak sapi potong. Jalur distribusi pemasaran pada masa pandemi covid-19 dapat dilihat pada Tabel 2. di bawah ini : 
Tabel 2. Rataan Margin dan keuntungan saluran pemasaran masa pandemi (Rp/ekor)

\begin{tabular}{|c|c|c|c|c|c|c|}
\hline No & Uraian & Saluran I & Saluran II & Saluran III & Saluran IV & Saluran V \\
\hline \multirow[t]{4}{*}{1} & Peternak* & & & & & \\
\hline & Biaya Pemeliharaan & $1,000,000$ & $1,000,000$ & $1,500,000$ & $3,000,000$ & $1,000,000$ \\
\hline & Harga Jual & $5,000,000$ & $5,000,000$ & $6,000,000$ & $9,000,000$ & $5,000,000$ \\
\hline & Keuntungan & $4,000,000$ & $4,000,000$ & $4,500,000$ & $6,000,000$ & $4,000,000$ \\
\hline \multirow[t]{8}{*}{2} & Pedagang Pengumpul* & & & & & \\
\hline & Harga Beli & & $5,000,000$ & $6,000,000$ & & \\
\hline & Angkut & & 50,000 & 50,000 & & \\
\hline & Tenaga Kerja & & 50,000 & 50,000 & & \\
\hline & Total Biaya Pemasaran & & 100,000 & 100,000 & & \\
\hline & Harga Jual & & $7,500,000$ & $6,500,000$ & & \\
\hline & Marjin & & $2,500,000$ & 500,000 & & \\
\hline & Keuntungan & & $2,400,000$ & 400,000 & & \\
\hline \multirow[t]{9}{*}{3} & Pedagang Besar* & & & & & \\
\hline & Harga Beli & & $7,500,000$ & & & \\
\hline & Angkut & & 100,000 & & & \\
\hline & Pakan & & 25,000 & & & \\
\hline & Tenaga Kerja & & 50,000 & & & \\
\hline & Total Biaya Pemasaran & & 175,000 & & & \\
\hline & Harga Jual & & $8,000,000$ & & & \\
\hline & Marjin & & 500,000 & & & \\
\hline & Keuntungan & & 325,000 & & & \\
\hline \multirow[t]{10}{*}{4} & Pedagang Pemotong* & & & & & \\
\hline & Harga Beli & & & $6,500,000$ & $9,000,000$ & \\
\hline & Angkut & & & 50,000 & 50,000 & \\
\hline & Pakan & & & 25,000 & 25,000 & \\
\hline & Tenaga Kerja & & & 150,000 & 150,000 & \\
\hline & Pengemasan & & & 120,000 & 130,000 & \\
\hline & Total Biaya Pemasaran & & & 345,000 & 355,000 & \\
\hline & Harga Jual & & & $10,000,000$ & $13,000,000$ & \\
\hline & Marjin & & & $3,500,000$ & $4,000,000$ & \\
\hline & Keuntungan & & & $3,155,000$ & $3,645,000$ & \\
\hline \multirow[t]{11}{*}{5} & Pedagang Pasar* & & & & & \\
\hline & Harga Beli & & & $10,000,000$ & & $5,000,000$ \\
\hline & Angkut & & & 50,000 & & 50,000 \\
\hline & Total Biaya Pemasaran & & & 50,000 & & 50,000 \\
\hline & Harga Jual & & & $12,000,000$ & & $9,000,000$ \\
\hline & Marjin & & & $2,000,000$ & & $4,000,000$ \\
\hline & Keuntungan & & & $1,950,000$ & & $3,950,000$ \\
\hline & Konsumen* & & & & & \\
\hline & Harga Beli & $5,000,000$ & $8,000,000$ & $12,000,000$ & $13,000,000$ & $9,000,000$ \\
\hline & Biaya-biaya & 25,000 & & & & \\
\hline & Keuntungan & $4,975,000$ & & & & \\
\hline \multicolumn{2}{|c|}{ Margin tiap Saluran Pemasaran } & 0 & $3,000,000$ & $6,000,000$ & $4,000,000$ & $4,000,000$ \\
\hline \multicolumn{2}{|c|}{ Keuntungan Dari Masing-masing Lembaga } & $8,950,000$ & $6,725,000$ & $10,005,000$ & $9,645,000$ & $7,950,000$ \\
\hline \multicolumn{2}{|c|}{$\begin{array}{l}\text { Keuntungan pemasaran dari Seluruh } \\
\text { Lembaga }\end{array}$} & & & & & $34,325,000$ \\
\hline
\end{tabular}

Tabel 2, menggambarkan keuntungan yang didapatkan pada masa pandemi covid-19 rata-rata semua jalur distribusi mendapatkan keuntungan lebih dari keuntungan jalur distribusi pemasaran sebelum masa pandemi covid19, keuntungan yang paling banyak didapatkan oleh jalur distribusi pemasaran III, pada masa pandemi selanjutnya jalur distribusi pemasaran IV, I, V dan jalur distribusi pemasaran II. Keuntungan margin adalah keuntungan yang bersifat kotor dari segi bisnis, keuntungan ini bersifat semu karena ada unsur-unsur biaya yang tidak diperhitungkan yaitu biaya tetap, sehingga besarnya keuntungan margin sama dengan selisih total output dengan biaya operasional. Akibat dari kondisi pandemic 19 juga berakibat konsumen akan membayar dengan harga 
yang tinggi dan produsen menerima biaya kerugian yang ditimbulkan pasar dan dari gangguan external atau internal Untuk meningkatkan keuntungan adalah dengan tidak lain dengan cara memperbaiki pelaksanan dari fungsi tataniaga secara efektif dan efisien. Pada pokoknya laba dapat diperoleh dari seluruh penghasilan dikurangi dengan seluruh biaya. Laba bersih yang dapat dicapai menjadi ukuran sukses bagi sebuah lembaga pemasaran. Margin pemasaran dapat diterima oleh pedagang perantara sebesar $62,17 \%$; pedagang antar pulau sebesar $29.30 \%$, bergantung kondisi dan lokasi pemasaran (Lalus, M. F 2019). tingginya biaya pemasaran akan mempengaruhi harga pada tingkat petani, keadaan ini dapat dimaklumi karena setiap lembaga memerlukan biaya yang tidak sedikit agar tidak menderita kerugian (Baharudin Pabbo 2016) dan (Munandi L.M, dkk, 2021).

\section{Efisiensi Pemasaran}

Tingkat efisiensi pemasaran sapi potong di Kabupatern Gorontalo menunjukkan nilai yang berbeda-beda dalam setiap jalur distribusi pemasaran. Nilaai efisiensi pemasaran dipengaruhi oleh biaya-biaya yang dikeluarkan dan nilai produk (sapi potong) yang di pasarkan. Tingkat efisiensi pemasaran disetiap tingkat jalur distribusi pemasaran baik sebelum masa pandemi covid-19 dan pada masa pandemi covid-19 dapat dilihat pada Tabel 3 sebagai berikut :

Tabel 3 : Efisiensi Jalur distribusi Pemasaran Pada Masa Pandemi Covid-19

\begin{tabular}{lrr}
\hline \multicolumn{1}{c}{ Uraian } & $\begin{array}{c}\text { Masa Pandemi } \\
\text { Covid-19 }\end{array}$ & Ket \\
\hline Jalur distribusi Pemasaran I & $0,5 \%$ & Efisien \\
Jalur distribusi Pemasaran II & $3,43 \%$ & Tidak Efisien \\
Jalur distribusi Pemasaran III & $4,12 \%$ & Tidak Efisien \\
Jalur distribusi Pemasaran IV & $1,25 \%$ & Tidak Efisien \\
Jalur distribusi Pemasaran V & $0,05 \%$ & Efisien \\
\hline
\end{tabular}

Pada Tabel 3, terlihat bahwa tingkat efisiensi jalur distribusi pemasaran pada masa pandemi covid-19 jalur distribusi pemasaran I dan Jalur distribusi Pemasaran V efisien, sementara terdapat tiga jalur distribusi pemasaran yang tidak efisien baik. Hal ini dikarenakan nilai yang di peroleh lebih dari 1 sementara dikatakana efisien jika nilai yang didapatkan lebih kecil dan juga dikatakan efisien karena biaya pemasaran yang dikeluarkan kecil sementara harga pengambilan/harga pembelian besar, sedangkan tidak efisien karena biaya pemasaran besar/tinggi, sementara harga pembelian kecil. Tingkat efisiensi jalur distribusi pemasaran I sebesar 0,5\% hal ini terjadi karena biaya pemeliharaan pada masa pandemi lebih sedikit di bandingkan dengan biaya pemeliharaan.
Hal ini sejalan dengan yang dinyatakan oleh Hastang, dkk (2013); Lasaharu (2020); Agustin, M., \& Hayati, M. (2020) efisiensi pemasaran dapat lebih baik jika biaya pemasaran diminimalisasikan, sehingga keuntungan pemasaran dapat lebih tinggi, presentase perbedaan harga yang dibayarkan konsumen dan produsen tidak terlalu tinggi, tersediannya fasilitas fisik pemasaran dan adanya kompotisi pasar yang sehat.

\section{KESIMPULAN}

Jalur distribusi pemasaran pada masa pandemi terdapat 2 jalur pemasaran yakni secara langsung dan tidak langsung. Tingkat efisiensi jalur distribusi terdapat pada jalur pemasaran I dan $\mathrm{V}$ 


\section{DAFTAR PUSTAKA}

Abdi, Usman Rianse. 2012. Metodologi Penelitian Sosial dan Ekonomi Teori dan Aplikasi. Bandung. Alfabeta.

Anugrah, I. S., Saputra, Y. H., \& Sayaka, B. (2020). Dampak Pandemi Covid-19 pada Dinamika Rantai Pasok Pangan Pokok. Jurnal Sosial Ekonomi Pertanian.

Agustin, M., \& Hayati, M. (2020). PEMASARAN SAPI POTONG DI DESA LOBUK KABUPATEN SUMENEP. Agrisocionomics: Jurnal Sosial Ekonomi Pertanian, 4(1), 14-21.

Anugrah, I. S., Saputra, Y. H., \& Sayaka, B. DAMPAK PANDEMI COVID-19 PADA DINAMIKA RANTAI PASOK PANGAN POKOK.

Baharudin Pabbo, 2016. Margin Pemasaran Sapi Bali Pada Kelompok Tani Ramah Lingkungan Di Desa Galung Kecamatan Barru Kabupaten Barru. Jurnal Hal 1 di akses pada tanggal 12 februari 2020.

Hakim, A., Sembada, P., \& Andik, S. D. S. (2021). Dampak Pandemi Covid-19 terhadap Peternakan Hewan Qurban di Kota Sukabumi dan Kabupaten Bogor, Studi Kasus: Zona Hijau dan Merah. Jurnal Ilmu Produksi dan Teknologi Hasil Peternakan, 9(3), 120-126

Hastang, dkk 2013. Margin Dan Keuntungan Lembaga Pemasaran Sapi
Potong Dari Kabupaten Bone Ke Kota Makassar. Jurnal Hal 1 di akses pada tanggal 13 februari 2020.

Lasaharu, N. A., \& Boekoesoe, Y. (2020). ANALISIS PEMASARAN SAPI POTONG. Jambura Journal of Animal Science, 2(2), 62-75. https://doi.org/10.35900/jjas.v2i2.50 92

Lalus, M. F., Krova, M., Ratu, M. R. D., \& Nono, O. H. (2019). Analisis Distribusi Margin Di Antara Lembaga-Lembaga Pemasaran Ternak Sapi Potong Di Kabupaten Kupang Nusa Tenggara Timur (Anaysis of margin distribution between marketing beef cattle institutions in Kupang District East Nusa Tenggara). Jurnal Nukleus Peternakan, 6(2), 63-70.

Munandi L.M, (2021). Potensi Pengembangan Ternak Sapi Potong Terintegrasi Tanaman Kelapa Dalam.Jambura Journal of Animal Science. 3(2), 62-70

Noor TI. 2020. Ketahanan pangan Indonesia: pendekatan multidimensi. Materi presentasi Webinar Kaprodi Magister Ekonomi Pertanian, Fakultas Pertanian Unpad;2020Sep 24; Sumedang, Indonesia.

Sudarmono dan Sugeng. 2008. Sapi Potong. Penebar Swadaya. Jakarta. 